have diminished with increasing experience, but recent attempts to manufacture polyvalent vaccines containing poliomyelitis antigen have raised some special problems. Experience with such multiple antigens is still too limited for their value to be assessed.

The safety of live poliomyelitis vaccines appears to have been satisfactorily demonstrated in a number of areas where they have been used on a large scale, and, in all except two of these areas, the incidence of poliomyelitis has fa!len. It is still too soon, however, to evaluate the long-term effectiveness of live vaccines. Criteria for evaluating the safety and effectiveness of such vaccines are formulated in the report. In this connexion, further research on virus markers and on the degree of viræmia produced by different strains is urgently needed. The capacity of the various strains to spread contacts in the community is also a matter needing investigation. The Committee proposed criteria for the selection of suitable strains and for grading various strains of the three sets of vaccines in use. It also gave attention to the possible contamination of live poliovirus vaccines by simian viruses, and recommended the study of their pathogenicity and methods of differential inactivation.

The choice of inactivated or live virus vaccine for large-scale immunization programmes will depend on the epidemiological, social and economic circum. stances of the country concerned. The Committee examined the advantages and disadvantages of the two types of vaccine from these aspects and suggested a number of considerations to be kept in mind by public health authorities when deciding which policy to adopt. Emphasis is laid on the importance of serological surveys and surveillance for the efficient conduct of immunization programmes. Finally, attention is directed to the increasing prevalence of other enterovirus infections (Coxsackio and ECHO viruses) which cause a wide range of clinical manifestations sometimes resembling poliomyelitis. Continued research is needed in this field, especially to detect any increase in the severity of the clinical manifestations in special groups, for example, new-born infants.

\title{
UPPER WINDS OVER THE WORLD
}

T THE appearance of Geophysical Memoir No. 103 from the Meteorological Office will be welcomed by all who use upper-wind data, whether for geophysical or aviation purposes*. This supersedes Geophysical Memoir No. 85, which had the same title, and was published ten years ago, but has long been out of print. The present publication is based, almost entirely, on data for the five-year period 1949-53. Though the International Geophysical Year will have provided a wider coverage to greater beights, it will always be useful to have a detailed enalysis of the epoch 1949-53 for reference and comparison, particularly as the information is given for the months of January, April, July and October, rather than as averages for the three-monthly periods of four seasons. This latter procedure was adopted in Geophysical Memoir No. 85 on account of paucity of data, but results in excessive smoothing. Average contours are given at the pressure-levels 700, 500,

- Air Ministry : Meteorological Office. Geophysical Memoirs, No. 103 : Upper Winds over the World, Parts 1 and 2. By H. Heastie and P. M. Stephenson. Pp. i +217. (M.O. 631c.) (London : H.M. Stationery office, 1960.) 30s, net.
$300,200,150$ and $100 \mathrm{mb}$. (approximately 3,000$16,000 \mathrm{~m}$.) and also the average winds are given by diagrams of streamlines and isotachs. The North Polar regions have circumpolar charts for the regions north of $65^{\circ} \mathrm{N}$., but no data for the southern hemisphere are given south of $65^{\circ} \mathrm{S}$. This is because of the absence of data, for there are large areas of the southern oceans without observations and there must have been a great deal of guess-work there.

Meteorologists will be especially interested in the vertical cross-sections of average zonal wind and potential temperature given for the longitudes $140^{\circ} \mathrm{E}$., $75^{\circ} \mathrm{E} ., 10^{\circ} \mathrm{W} ., 75^{\circ} \mathrm{W} ., 130^{\circ} \mathrm{W}$. and $180^{\circ} \mathrm{W}$. for the same months. These illustrate very dramatically the complexities of atmospheric motions.

In order to estimate the probable wind at any point, it is also necessary to know the standard vector deviation, as well as the average wind. Charts of standard deviation are not provided, but it is promised that they will be given in a later publication.

\section{DIRECTION OF THE GEOMAGNETIC FIELD DURING THE TRIASSIC PERIOD IN SIBERIA}

\author{
By DR. E. R. DEUTSCH \\ Imperial Oil Research Laboratory, Calgary, Alberta \\ AND \\ N. D. WATKINS \\ Shell Oil Co. of Canada, Edmonton, Alberta
}

\begin{abstract}
A N earlier detailed study of the Deccan Trap $A$ formation ${ }^{1,2}$ revealed, wherever samples were taken, the existence of a stable remanent magnetization making large angles with the ambient field. One explanation has been that India was in middle latitudes of the southern hemisphere during the late Cretaceous or early Eocene. This would also conform
\end{abstract}

broadly to palæogeographical reconstructions offered in the literature, according to which India once formed part of a southern super continent the constituents of which later dispersed.

Such an interpretation prompts the question to what extent the rest of what is now Asia participated in the hypothetical northward drift of India. It 